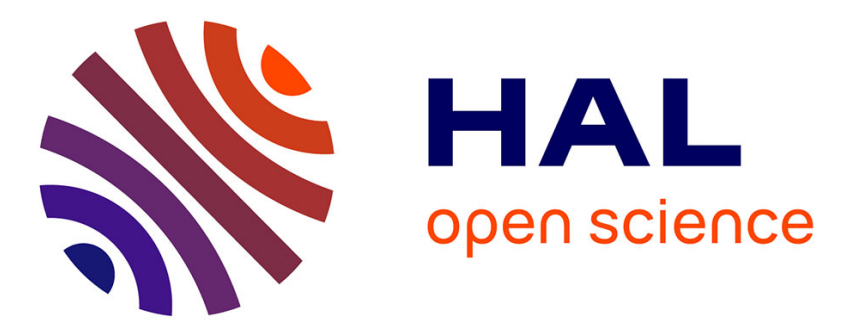

\title{
Quantitative arginine requirement of Atlantic salmon (Salmo salar) reared in sea water
}

S.P. Lall, Sadasivam S. Kaushik, Pierre-Yves Le Bail, R. Keith, J.S. Anderson, E. Plisetskaya

\section{- To cite this version:}

S.P. Lall, Sadasivam S. Kaushik, Pierre-Yves Le Bail, R. Keith, J.S. Anderson, et al.. Quantitative arginine requirement of Atlantic salmon (Salmo salar) reared in sea water. Aquaculture, 1994, 124, pp.13-25. 10.1016/0044-8486(94)90350-6 . hal-02716145

\section{HAL Id: hal-02716145 \\ https://hal.inrae.fr/hal-02716145}

Submitted on 1 Jun 2020

HAL is a multi-disciplinary open access archive for the deposit and dissemination of scientific research documents, whether they are published or not. The documents may come from teaching and research institutions in France or abroad, or from public or private research centers.
L'archive ouverte pluridisciplinaire HAL, est destinée au dépôt et à la diffusion de documents scientifiques de niveau recherche, publiés ou non, émanant des établissements d'enseignement et de recherche français ou étrangers, des laboratoires publics ou privés. 


\title{
Quantitative arginine requirement of Atlantic salmon (Salmo salar) reared in sea water
}

\author{
S.P. Lall ${ }^{\text {a,* }}$, S.J. Kaushik ${ }^{\text {, P.Y. Le Bail }}{ }^{\text {, R. Re Keith }}{ }^{\mathrm{a}}$, J.S. Anderson ${ }^{\mathrm{a}, 1}$, \\ E. Plisetskaya ${ }^{\mathrm{d}}$ \\ ${ }^{a}$ Biological Sciences Branch, Department of Fisheries and Oceans, P.O. Box 550, Halifax, NS, B3J \\ 2S7 Canada \\ ${ }^{\mathrm{b}}$ Laboratoire de Nutrition des Poissons, INRA, 64310 Saint Pée-sur-Nivelle, France \\ 'Station de Physiologie des Poissons, INRA, Campus de Beaulieu, 35042 Rennes, France \\ ${ }^{d}$ School of Fisheries HF-15, University of Washington, Seattle, WA 98195, USA
}

\begin{abstract}
A study utilizing casein-corn gluten meal based diets supplemented with crystalline amino acids was conducted to determine the quantitative arginine requirement of Atlantic salmon smolts. Fish were gradually acclimated to sea water ( $32 \mathrm{ppt}$ ) and maintained for 8 weeks prior to commencement of the study. Triplicate groups of Atlantic salmon were fed to satiation diets (CP: 40\% DM) containing 1.1-3.2 g Arg/100 g diet (2.7-8\% of protein) for a period of 8 weeks. Growth, feed utilization and nitrogen retention data showed the requirement for arginine of Atlantic salmon to be $1.6 \%$ of dry matter (4.1\% of dietary protein). An arginine requirement of $1.6 \%$ of dry matter (4.1\% of dietary protein) was also obtained from broken-line regression of expired ${ }^{14} \mathrm{CO}_{2}$ (following an intraperitoneal injection of $\mathrm{L}-\left[\mathrm{U}-{ }^{14} \mathrm{C}\right]$ arginine versus dietary concentration. Except for the loss of appetite resulting in a low feed intake and depressed growth, no nutritional deficiency signs were observed in fish fed an arginine deficient diet for 98 days. The significance of several biochemical indices measured including liver arginase activity and plasma arginine, insulin and growth hormone levels of fish fed graded levels of arginine supplement is also discussed.
\end{abstract}

\section{Introduction}

Arginine is an indispensable amino acid necessary for optimal growth of young fish (Wilson, 1989) and terrestrial animals (Visek, 1984). The quantitative re-

\footnotetext{
*Corresponding author.

${ }^{1}$ Present address: Department of Animal Science, University of British Columbia, Vancouver, BC, Canada V6T 2A1.
} 
quirement for arginine has been measured in several species of fish grown in freshwater (Nose, 1979; Robinson et al., 1981; Santiago and Lovell, 1988). The values obtained in salmonids, particularly for rainbow trout, using conventional growth response criterion show wide variations (Wilson, 1989). Results from several studies (Kaushik, 1979; Walton et al., 1986; Chiu et al., 1988; Kaushik et al., 1988; Cho et al., 1992; Kim et al., 1992) show requirement values ranging from 3.0 to $4.5 \%$ of dietary protein based on growth, nitrogen retention and several biochemical criteria. Ketola (1983) reported a requirement level of 5.4-5.9\% of dietary protein for maximal growth rate of rainbow trout, similar to values found by Klein and Halver (1970) for chinook salmon, whereas Ogino (1980) estimated a requirement of $3.5 \%$ of protein based on arginine retention in the body. Some of these variations in the arginine requirement of salmonid fishes may be due to basal diet composition, size and age of fish, genetic differences, feeding rate and culture conditions all of which affect overall growth rate.

Atlantic salmon are the most economically important farmed salmon species in Europe, North America and Chile. Their feed formulations are generally based upon the recommendations of the NRC (1981). Despite successful marine farming of this species, to date, studies on its amino acid requirement are confined to that for lysine (Anderson et al., 1993) in Atlantic salmon grown in freshwater. The main objective of the present study was to quantify the dietary requirement of arginine for Atlantic salmon reared in sea water and to examine the effects of feeding graded levels of arginine on the oxidation of a tracer dose of L$\left[{ }^{14} \mathrm{C}\right]$ arginine. The amino acid oxidation technique developed for measuring the amino acid requirement of mammals has also been successfully adapted for fish (Kaushik and Fauconneau, 1984; Walton et al., 1984; Anderson et al., 1993). When animals are fed an amino-acid-deficient or imbalanced diet, the oxidation rate of the same amino acid is low. The oxidation rate gradually increases to stabilize when the level of amino acid supplied in the diet is optimal to meet the requirement of fish. Other biochemical parameters (hepatic activities of arginase and post-prandial blood arginine concentration) were also used to further confirm the requirement values obtained by data on growth rate and arginine oxidation.

Amino acids are considered insulinotropic in fish (Plisetskaya et al., 1976). Recently, Plisetskaya et al. (1991) found that feeding coho salmon, chinook salmon and rainbow trout with arginine-supplemented diets caused an elevation of plasma insulin levels. A considerable amount of literature is available on the stimulatory effects of arginine on growth hormone and somatomedin release in mammals including man (Fajans and Floyd, 1972; Swanson 1990). A further objective of this study was to determine the effects of dietary arginine levels on plasma growth hormone and insulin levels in Atlantic salmon.

\section{Materials and methods}

Experimental design, fish, rearing system and diets

Atlantic salmon (Salmo salar) smolts obtained from Cobequid fish hatchery 
of the Department of Fisheries and Oceans were gradually acclimated over 2 weeks to ambient sea water $(32 \mathrm{ppt})$ at $5^{\circ} \mathrm{C}$. All fish were vaccinated against Vibrio anguillarum (Vibrogen, Aqua Health Ltd, Charlottetown) at the hatchery, approximately 5 weeks prior to moving them to the laboratory. After 2 weeks of adjustment during which the water temperature was gradually increased to $15^{\circ} \mathrm{C}$, fish were transferred to 200-liter circular fiber-glass tanks. Each tank was supplied with 3 liters per minute of heated sea water $\left(15 \pm 1^{\circ} \mathrm{C}\right)$ and a photoperiod controlled at $12 \mathrm{~h} \mathrm{light} / 12 \mathrm{~h}$ dark schedule during the experiment. Fish readily adjusted to the basal diet, aquaria and the standardized environmental conditions of the laboratory.

The basal diet (crude protein: $40 \%$ of dry matter) was formulated to be limiting in arginine while being adequate, according to the NRC (1981), in all other essential amino acids (EAA) . A fixed amount of the dietary protein $(30.5 \%)$ was supplied by casein and corn gluten meal and the remaining portion of the protein equivalent was made up by a crystalline amino acid premix (Table 1). The ap-

Table 1

Composition of basal experimental diet ${ }^{1}$

\begin{tabular}{lc}
\hline Ingredient & $\%$ \\
\hline Casein, vitamin free $^{2}$ & 15.0 \\
Corn gluten meal $^{3}(60 \% \mathrm{CP})$ & 25.0 \\
Agar $^{4}$, bacteriological $^{2}$ & 3.0 \\
L-Arginine free base & + \\
Dextrin $^{2}$, white & 13.0 \\
Cellulose $^{2}$ (Celufil) & 7.0 \\
Amino acid premix $^{5}$ & 13.0 \\
Vitamin premix $^{6}$ & 3.0 \\
Mineral premix $^{7}$ & 6.0 \\
Fish oil $^{8}$, herring & 15.0 \\
\hline
\end{tabular}

${ }^{1}$ Proximate analysis (\% as fed basis): dry matter, 92.8 ; crude protein ( $\left.\% \mathrm{~N} \times 6.25\right), 39.7$; total lipid, 15.6 ; ash, 3.9 ; gross energy, $21.1 \mathrm{~kJ} / \mathrm{g}$.

${ }^{2}$ US Biochemical Corp., Cleveland, $\mathrm{OH}$.

${ }^{3}$ Corey Feed Mills Ltd., Frederiction, NB.

${ }^{4}$ Spectrum Diagnostics, Glenwood, IL.

${ }^{5}$ Amino acid added to supply the following ( $\mathrm{g} \mathrm{L}$-form per $\mathrm{kg}$ of diet): alanine, 8; aspartic acid, 20; cystine, 2; glutamic acid, 40; glycine, 23; histidine, 3; isoleucine, 5 ; lysine, 7 ; methionine, 8 ; phenylalanine, 3; proline, 4; serine, 3; threonine, 2; tryptophan, 2.

${ }^{6} \mathrm{Vitamins}$ added to supply the following (per $\mathrm{kg}$ of diet): reinyl acetate, $8000 \mathrm{IU}$; cholecalciferol, $3000 \mathrm{IU}$; all-race- $\alpha$-tocopheryl acetate, $250 \mathrm{IU}$; menadione sodium bisulfite, $40 \mathrm{mg}$; thiamine $\cdot \mathrm{HCL}$, $50 \mathrm{mg}$; riboflavin, $70 \mathrm{mg}$; calcium $d$-pantothenate, $200 \mathrm{mg}$; biotin, $1.5 \mathrm{mg}$; folic acid, $20 \mathrm{mg}$; vitamin $\mathrm{B}_{12}, 0.15 \mathrm{mg}$; niacin, $300 \mathrm{mg}$; pyridoxine $\cdot \mathrm{HCL}, 50 \mathrm{mg}$; choline chloride, $2 \mathrm{~g}$; ascorbic acid, $700 \mathrm{mg}$; inositol, $500 \mathrm{mg}$.

${ }^{7}$ Minerals added to supply the following (per $\mathrm{kg}$ of diet): calcium phosphate $(15.9 \% \mathrm{Ca}, 24.6 \% \mathrm{P})$, $14.3 \mathrm{~g}$; potassium phosphate $(22.8 \% \mathrm{P}, 28.7 \% \mathrm{~K}), 6.6 \mathrm{~g}$; manganous sulfate $(32.5 \% \mathrm{Mn}), 123.1 \mathrm{mg}$; ferrous sulfate $(20.1 \% \mathrm{Fe}), 248.7 \mathrm{mg}$; copper sulfate $(25.4 \% \mathrm{Cu}), 39.5 \mathrm{mg}$; zinc sulfate $(22.7 \% \mathrm{Zn})$, $330 \mathrm{mg}$; cobalt chloride $(24.8 \% \mathrm{Co}), 20.2 \mathrm{mg}$; potassium iodide ( $76.5 \% \mathrm{I}), 6.5 \mathrm{mg}$; sodium selenite ( $45.6 \% \mathrm{Se}), 2.2 \mathrm{mg}$; sodium fluoride $(45.2 \% \mathrm{~F}), 10 \mathrm{mg}$.

${ }^{8}$ Stabilized with $0.05 \%$ ethoxyquin. 
parent digestibilities of dietary energy and protein was calculated to be 84.9 and $97.7 \%$ respectively, based on data obtained previously in the laboratory for the ingredients used in the present study. All experimental diets contained 18.6 MJ/ $\mathrm{kg}$ of digestible energy (DE) and the digestible protein (DP) to DE ratio was kept constant at $20 \mathrm{~g} / \mathrm{MJ}$. The level of arginine in unsupplemented diet, by analysis, was $2.7 \%$ of protein ( $1.1 \%$ of dry matter). The gradual increases in arginine concentration of experimental diets was made by weight for weight replacement of L-glutamic acid by L-arginine-free base in the amino acid premix. Each amino acid premix was blended with dissolved agar ( $150 \mathrm{~g}$ in $2 \mathrm{~kg}$ water) before being mixed with other ingredients similar to the method described by Cho et al. (1992). This process was adopted with the intention to slow down absorption of free amino acids for a period sufficiently long until the intact dietary proteins were digested. All the diets were pelleted with steam (Laboratory Pellet Mill, California Pellet Mill, San Francisco, CA) and stored at $-30^{\circ} \mathrm{C}$ until used.

Atlantic salmon were distributed in 15 lots of 45 fish each, each lot being adjusted to contain an equal biomass. The five experimental diets were fed to triplicate groups of fish for 14 weeks. The experiment consisted of a randomized complete block design, each diet being represented within each block. The fish were fed to satiety twice daily and weighed every 4 weeks and at the end of 14 weeks. Mortality was recorded daily and the feed consumption was measured weekly. Dead fish were examined for gross abnormality.

\section{$L-\left[U-{ }^{14} C\right]$ Arginine oxidation technique}

The method of Walton et al. (1984) was used for the oxidation procedure with some modifications. A solution of $\mathrm{L}-\left[\mathrm{U}-{ }^{14} \mathrm{C}\right]$ arginine $\left(282 \mathrm{mCi} \cdot \mathrm{mmol}^{-1}(10.4\right.$ $\mathrm{GBq} \cdot \mathrm{mmol}^{-1}$ ), Amersham Canada Ltd., Oakville, Ont.) was prepared in sterile $0.15 \mathrm{M}$ sodium chloride so that $100 \mu \mathrm{l}$ contained $1 \mu \mathrm{Ci}$ ( $37 \mathrm{kBq}$ ). After 100 days, one fish, selected at random, from each dietary treatment was held in a 20-liter polyethylene pail containing 15 liters of seawater and 10 mM HEPES (pH 7.35) at $15^{\circ} \mathrm{C}$. A $1 \mu \mathrm{Ci}(37 \mathrm{kBq})$ portion of the radioactive solution was injected intraperitoneally into the fish at $13.00 \mathrm{~h}$. The ${ }^{14} \mathrm{CO}_{2}$ respired between then and 09.00 $\mathrm{h}$ the following day for a total of $20 \mathrm{~h}$ was collected into two $\mathrm{CO}_{2}$ traps. The traps consisted of two 125-ml Erlenmeyer flasks, connected in series, each containing $50 \mathrm{ml}$ ethanolamine/ethylene glycol monomethyl ether $(1: 2 \mathrm{v} / \mathrm{v})$. The fish were removed from the containers and the water acidified ( $\mathrm{pH} \mathrm{1-2)}$ with concentrated $\mathrm{HCl}$ and collection of $\mathrm{CO}_{2}$ continued for an additional $2 \mathrm{~h}$. The contents of the two $\mathrm{CO}_{2}$ traps were then combined and made up to $100 \mathrm{ml}$ with distilled water. Samples of acidified water were collected from each pail to determine residual radioactivity. This procedure was repeated for 3 fish from each dietary treatment.

A $1 \mathrm{ml}$ aliquot of each sample was added to $10 \mathrm{ml}$ of a scintillation cocktail (Beckman Ready Solv-Hp, Beckman Instruments, 2500 Harbor Boulevard, Fullerton, CA) and radioactivity measured on a Beckman LS 3801, liquid scintillation system (Beckman Instruments, 2500 Harbor Boulevard, Fullerton, CA). 
Analytical procedures

Dietary arginine levels were determined by the method of Gehrke et al. (1985), on a Beckman System 6300, High Performance Amino Acid Analyzer (Beckman Instruments, 2500 Harbor Boulevard, Fullerton, CA ). Duplicate samples of each diet were analyzed for dry matter, crude protein $(\mathrm{N} \times 6.25)$ and ash using the methods of the AOAC (1990). Lipid content of the diet was determined by the method of Bligh and Dyer (1959). After the final growth measurements (98 days) fish were starved for $48 \mathrm{~h}$. Six fish from each tank were killed and immediately frozen in liquid nitrogen and stored at $-40^{\circ} \mathrm{C}$ until analyzed. Lyophilized carcass samples were analyzed for moisture, protein and lipid by the same methods as used for experimental diets.

For plasma hormone assays and amino acid analysis, fish were anesthetized in a solution of 2-phenoxyethanol $(0.5 \mathrm{ml} / \mathrm{l}$ of water $)$. Blood was collected from the caudal vein of fish, 6 and $18 \mathrm{~h}$ after the last meal, with an EDTA-coated syringe and centrifuged at $3000 \times g$. Care was taken to withdraw blood from individual fish within a very short interval after capture in order to minimize any possible effect of stress on circulating hormone levels. Plasma was stored at $-70^{\circ} \mathrm{C}$ until analysis. Insulin and growth hormone were determined according to the methods of Plisetskaya et al. (1986) and Le Bail et al. (1991) respectively. For amino acid analysis, plasma samples collected after $6 \mathrm{~h}$ of fasting were deproteinized by addition of three volumes of $0.2 \mathrm{M} 5$-sulfosalicylic acid and the precipitated protein removed by centrifugation. Plasma free arginine was determined by High Performance Amino Acid Analyzer.

All data were analyzed by the analysis of variance. Significance $(P<0.05)$ of differences between treatment means was evaluated using the orthogonal comparison test or Duncan's multiple range test as outlined by Steel and Torrie (1960). The arginine requirement was determined by broken-line regression analysis (Brookes et al., 1972; Zeitoun et al., 1976; Robbins et al., 1979) of percentage weight gain against dietary arginine level (\% dry matter basis) and of recovered ${ }^{14} \mathrm{CO}_{2}$, expressed as a percentage of the injected L- $\left[\mathrm{U}-{ }^{14} \mathrm{C}\right]$ arginine, versus dietary arginine level (\% DM). The model used was:

$$
Y=L-B R+B X
$$

where $L$ is the ordinate, $R$ is the arginine requirement, $B$ is the slope, and $X$ is the dietary arginine level. $L-B R$ forms the intercept of the model and by definition $B=0$ when $X>R$.

\section{Results}

The data presented in Table 2 clearly indicate that final live weight, weight gain, daily growth coefficient and feed efficiency of fish fed diet containing $1.1 \%$ arginine $(2.7 \%$ of protein ) were significantly lower than in fish fed higher amounts of arginine. However, the increase in the level of arginine above $1.6 \%$ of the diet ( $4.1 \%$ of protein) had no significant $(P<0.05)$ effect on various growth param- 


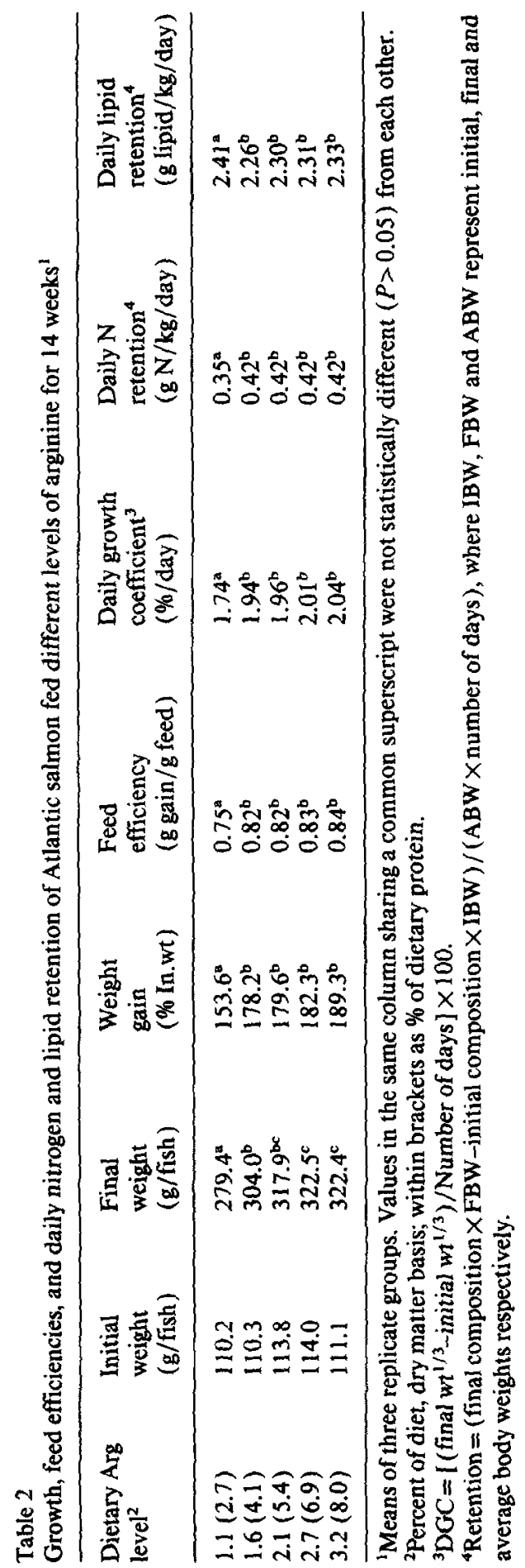


Table 3

Effect of dietary arginine intake on plasma arginine concentration and arginase activities in liver and kidney of Atlantic salmon

\begin{tabular}{llll}
\hline $\begin{array}{l}\text { Dietary Arg } \\
\text { level } \\
(\% \mathrm{DM})\end{array}$ & $\begin{array}{l}\text { Plasma Arg } \\
\text { level } \\
(\mathrm{mM})\end{array}$ & \multicolumn{2}{l}{$\begin{array}{l}\text { Arginase activity } \\
(\mu \mathrm{mol} \text { urea/h/mg protein })\end{array}$} \\
\cline { 2 - 4 } & & Liver & Kidney \\
\hline 1.1 & $0.51 \pm 0.04^{\mathrm{a}}$ & $53.8 \pm 3.94$ & $38.7 \pm 4.65$ \\
1.6 & $0.55 \pm 0.05^{\mathrm{ab}}$ & $59.9 \pm 5.95$ & $39.8 \pm 5.23$ \\
2.1 & $0.65 \pm 0.03^{\mathrm{bc}}$ & $58.3 \pm 3.21$ & $42.7 \pm 6.24$ \\
2.7 & $0.71 \pm 0.04^{\mathrm{c}}$ & $63.7 \pm 6.18$ & $44.3 \pm 5.10$ \\
3.2 & $0.75 \pm 0.04^{\mathrm{c}}$ & $63.9 \pm 5.54$ & $53.4 \pm 5.41$
\end{tabular}

${ }^{1}$ Mean \pm standard error. Values in the same column sharing a common superscript were not statistically different $(P>0.05)$ from each other.

Table 4

Percent of injected L- $\left[\mathrm{U}_{-}{ }^{14} \mathrm{C}\right]$ arginine recovered as ${ }^{14} \mathrm{CO}_{2}$ from Atlantic salmon fed diets with graded levels of arginine ${ }^{1}$

\begin{tabular}{ll}
\hline $\begin{array}{l}\text { Dietary Arg } \\
\text { level } \\
(\% \mathrm{DM})\end{array}$ & $\begin{array}{l}\text { \% of injected } \\
\text { L- }\left[\mathrm{U}^{14} \mathrm{C}\right] \text { arginine } \\
\text { recovered as } \mathrm{CO}_{2}\end{array}$ \\
\hline 1.1 & $4.59 \pm 1.14^{\mathrm{a}}$ \\
1.6 & $10.86 \pm 1.27^{\mathrm{b}}$ \\
2.1 & $11.70 \pm 1.24^{\mathrm{b}}$ \\
2.7 & $12.12 \pm 0.79^{\mathrm{b}}$ \\
3.2 & $12.10 \pm 1.08^{\mathrm{b}}$ \\
\hline
\end{tabular}

'Mean \pm standard error. Values followed by the same letter were not significantly different $(P>0.05)$ according to Duncan's multiple range test.

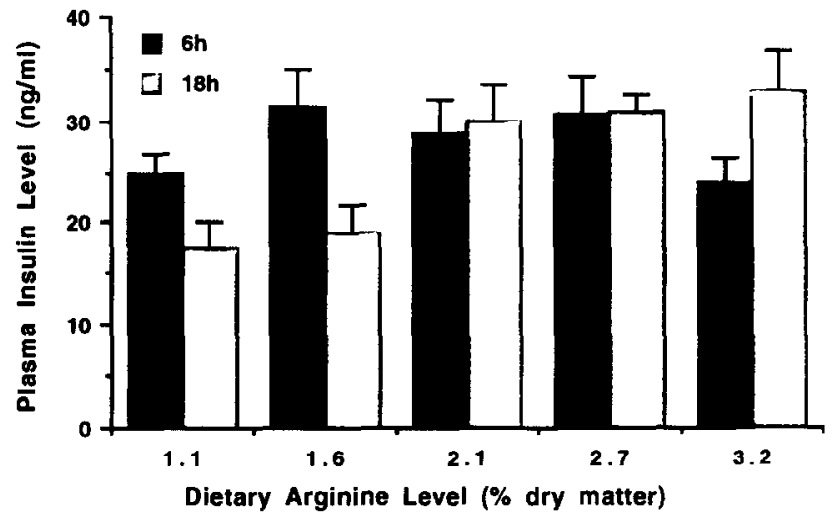

Fig. 1. Plasma insulin concentrations in Atlantic salmon, 6 and $18 \mathrm{~h}$ after feeding graded levels of dietary arginine. 


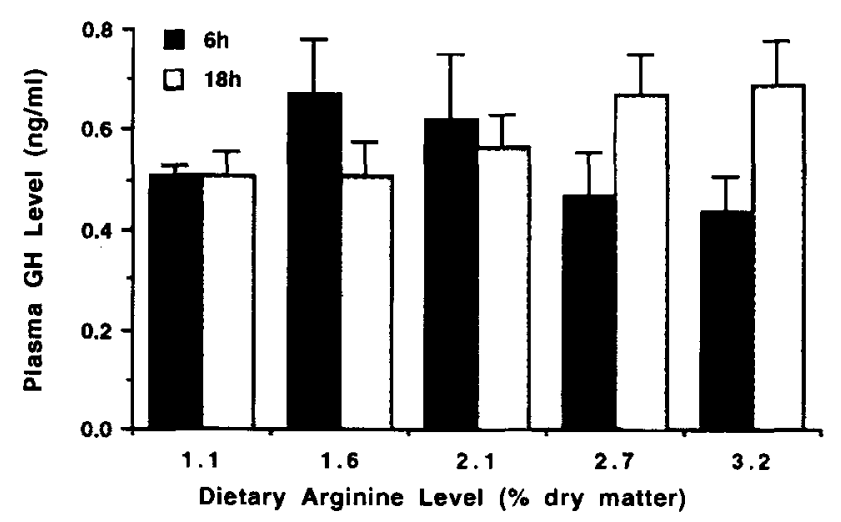

Fig. 2. Concentrations of growth hormone (GH) in the plasma of Atlantic salmon, 6 and $18 \mathrm{~h}$ after feeding graded levels of dietary arginine.

eters and feed efficiency. Orthogonal comparison in regression of treatment means from these parameters confirmed the arginine requirement value of $1.6 \%$ of the diet $(4.1 \%$ of dietary protein $)$ for maximum growth.

A similar response was also apparent for daily nitrogen and lipid retention where fish fed the lowest level of arginine showed significantly $(P<0.05)$ reduced lipid and protein retention than other dietary treatments. No gross pathology or mortality due to diets were observed during the 14-week experimental period. Plasma free arginine concentration, measured approximately $6 \mathrm{~h}$ post-prandial, increased with the increase in dietary arginine levels between 1.6 and $2.7 \%(4.1$ and $6.9 \%$ of protein) (Table 3 ). Arginase activities in the liver and kidney of Atlantic salmon ranged from 54 to 64 and from 39 to $53 \mu \mathrm{mol} u \mathrm{urea} / \mathrm{h} / \mathrm{mg}$ protein, respectively (Table 3 ). No significant effects due to the dietary arginine levels were observed on the arginase activities in liver and kidney. It was thus not possible to determine the requirement values on the basis of tissue arginase activity.

The percent of injected $\mathrm{L}-\left[\mathrm{U}-{ }^{14} \mathrm{C}\right.$ ]arginine recovered as ${ }^{14} \mathrm{CO}_{2}$ (Table 4) indicates that, as dietary arginine level increased, the amount of injected radiolabelled arginine oxidized to release carbon dioxide increased significantly $(P<0.05)$ to the arginine level of $1.6 \%(4.1 \%$ of protein $)$. Results showed that as the dietary arginine level increased past the requirement level, excess arginine was catabolized, thus releasing $\mathrm{CO}_{2}$. Percent of injected $\mathrm{L}-\left[\mathrm{U}-{ }^{14} \mathrm{C}\right]$ arginine recovered as ${ }^{14} \mathrm{CO}_{2}$ increased from $4.6 \%$ to about $11 \%$ and a plateau was reached. Regression analysis of these data versus dietary arginine (\% of dry diet) further confirmed the dietary arginine requirement of $1.6 \%(4.1 \%$ of protein $)$ determined by growth parameters.

Effects of dietary arginine intake on circulating plasma insulin and growth hormone (GH) concentrations, 6 and $18 \mathrm{~h}$ post-feeding various experimental diets are presented in Figs. 1 and 2. Plasma insulin concentration was very high and ranged from 18 to $32 \mathrm{ng} / \mathrm{ml}$ in fish fed low dietary levels of arginine (1.1 and 
$1.6 \%$ of diet); there was a tendency (not statistically significant in all cases) of declining titres at $18 \mathrm{~h}$ post-feeding as compared to $6 \mathrm{~h}$ after meal. For instance, insulin concentrations in Atlantic salmon fed the diet containing $1.6 \%$ arginine were $31.4 \pm 3.5$ and $19.0 \pm 3.2 \mathrm{ng} / \mathrm{ml}$ at 6 and $18 \mathrm{~h}$ respectively. No such tendency was observed in fish fed higher levels of arginine. Concentrations of growth hormone (GH) were very low and ranged between 0.4 and $0.6 \mathrm{ng} / \mathrm{ml}$. In fish fed low levels of dietary arginine (1.1 and $1.6 \%$ ), concentrations of both hormones were slightly, but not significantly, lower than in those fed higher levels of arginine.

\section{Discussion}

Available data on the quantitative arginine requirements of different fish show some degree of variation (Wilson, 1989). This is especially true in the case of the quantitative requirement for arginine of rainbow trout which has been extensively studied (Kaushik, 1979; Ketola, 1983; Walton et al., 1986; Chiu et al., 1988; Kaushik et al., 1988; Cho et al., 1992; Kim et al., 1992). From these studies, except that of Ketola (1983), it appears that the arginine requirement of rainbow trout is close to or below $4 \%$ of dietary protein. This is about one third below the values recommended by the NRC (1981) based on data obtained in two species of Pacific salmon by Klein and Halver (1970). In some of the earlier studies, difficulties in the precise estimation of requirements were due to the poor growth response of the fish. In the present study, all fish (except those fed the diet deficient in arginine) accepted the experimental diets very well and the growth rates of the fish were good.

Despite the significant increase in the intensive culture of Atlantic salmon in different parts of the world, there is practically no information on the quantitative essential amino acid requirements for this species. The only available information is for lysine which was estimated to be $1.84 \pm 0.16 \%$ of the dry diet $(4 \pm 0.35 \%$ of dietary protein $)$ in Atlantic salmon fingerlings grown in freshwater (Anderson et al., 1993). Results obtained in this study on Atlantic salmon in seawater using criteria of growth, feed efficiency and nutrient retention (Table 2 ) showed that the arginine requirement is $4.1 \%$ of protein ( $1.6 \%$ of diet), comparable to the reliable estimates made with rainbow trout under good growth conditions. Indirect evidence of this absence of difference between rainbow trout and Atlantic salmon in the requirements for indispensable amino acids has already been provided by Wilson and Cowey (1985) who found no significant differences in the amino acid composition of the whole body of these two species.

Use of plasma arginine concentrations as supportive data to confirm requirement values obtained through growth studies has met with variable success in the case of salmonids (Kaushik, 1979; Walton et al., 1986; Cho et al., 1992). Results on plasma arginine concentration in the present study corraborated relatively well with the data on growth parameters. Data on plasma arginine concentrations (Table 3 ) and on arginine oxidation (Table 4) confirmed that the arginine requirement of Atlantic salmon is $4.1 \mathrm{~g} / 16 \mathrm{~g} \mathrm{~N}$. Expressed per unit DE, the arginine 
requirement of Atlantic salmon is $0.88 \mathrm{~g} \mathrm{Arg} / \mathrm{kJ} \mathrm{DE}$, which is very similar to values reported earlier for the rainbow trout $(0.84 \mathrm{~g} \mathrm{Arg} / \mathrm{kJ} \mathrm{DE})$ by Cho et al. (1992), but lower than the values of $0.97 \mathrm{mg} \mathrm{Arg} / \mathrm{kJ}$ ME proposed by Chiu et al. (1988).

Besides its essentiality for protein synthesis, arginine is also involved in urea biosynthesis. Early studies by Luquet and Sabaut (1974) indicated that the arginine requirement of seabream (Chrysophrys aurata) was below $2.6 \%$ of dietary protein, while the requirements for three other indispensable amino acids (lysine, methionine and tryptophan) of this species were comparable to those reported for Pacific salmon. A possible low requirement for arginine was attributed to potentially high levels of urea cycle enzyme activities in marine teleosts (Huggins et al., 1969). Subsequently, Kaushik (1979) found that even in rainbow trout grown either in freshwater or in seawater, the arginine needs were lower than those estimated by Klein and Halver (1970). Chiu et al. (1986) found that rainbow trout have a functional urea cycle providing for potential biosynthesis of arginine and that citrulline can spare arginine to a certain extent. They also suggested that dietary electrolyte balance can affect arginine requirement for maximum growth to a certain extent (Chiu et al., 1988), although not significantly. It would be interesting to check whether there is any difference in the arginine requirement of Atlantic salmon due to parr-smolt transformation and depending upon water salinity.

Activities of amino acid catabolising enzymes vary considerably depending upon the nutritional status of animals. Arginase is distributed mainly in the mitochondrial fraction in both the liver and kidney of teleosts (Cvancara, 1969; Walton et al., 1986). The values on arginase activities measured during the present study are within the range of values recorded in the literature both for rainbow trout (Chiu et al., 1986; Walton et al., 1986) and for Atlantic salmon (Portugal and Aksnes, 1983). Our results also corroborate the findings of Walton et al. (1986) that it is not possible to determine arginine requirement values from the activities of arginase measured in the liver or kidney of fish fed graded levels of arginine.

Plasma insulin levels of Atlantic salmon observed in this study were higher than those reported (Plisetskaya et al., 1991 and personal communication) for any salmon species, including freshwater and seawater Atlantic salmon smolts reared at the US west coast and in Europe, but lower than those for rainbow trout. Sundby et al. (1991) found that in Atlantic salmon weighing about $100 \mathrm{~g}$, levels of plasma insulin peaked at about $20 \mathrm{ng} / \mathrm{ml}$ immediately after a meal and declined to $10 \mathrm{ng} / \mathrm{ml}$, about $6 \mathrm{~h}$ later. They also reported that absolute feed intake affected plasma insulin levels. In the study by Plisetskaya et al. (1991), injection of high doses of arginine led to a rise in plasma insulin levels of chinook and coho salmon. Diets containing very high levels of arginine (3.1-9.1\% of dry matter) significantly increased plasma insulin titers, not only in two species of Pacific salmon, but also in the rainbow trout (at a dietary arginine level of $9.1 \%$ of dry matter, the increase was from 60 to about $80 \mathrm{ng} / \mathrm{ml}$ ).

In the present study, we observed some, although statistically insignificant, de- 
cline in the plasma insulin concentrations $18 \mathrm{~h}$ after the meal. However, such decline could be seen only in fish fed low quantities of arginine (Fig. 1). When Atlantic salmon were fed higher levels of arginine, plasma insulin titres remained elevated even $18 \mathrm{~h}$ after the meal. These data suggest that arginine-caused effects on insulin production and/or metabolism may depend either on species differences or on the physiological conditions of a given species. It seems also more likely to observe an increase in systemic insulin levels only when fish are fed dietary arginine supplementation far exceeding the requirement levels.

Among the amino acids, the effects of arginine on GH release have been studied to a great extent in mammals. Injection or dietary supplementation of arginine has been shown to increase GH release and induce immune resistance in different animals (Visek, 1985, 1986; Swanson, 1990). Data on plasma levels of growth hormone obtained here are extremely low (about $0.5 \mathrm{ng} / \mathrm{ml}$ ) compared to values available for Atlantic salmon (Björnsson et al., 1988, 1989; Boeuf et al., 1989), for Pacific salmon or for rainbow trout (Le Bail et al., 1991; Pickering et al., 1991 ). Although the sampling and analytical protocol was essentially the same, the reason for such low values obtained in this study is not clear. Björnsson et al. $(1988,1989)$ showed that plasma GH levels can vary considerably in Atlantic salmon and that they are affected by a number of environmental and physiological parameters. Boeuf et al. (1989) observed very low concentrations of GH in the plasma of pre-smolts (values comparable to those found in the present study), but the levels increased during smolting and were stabilized at relatively high levels in seawater-adapted Atlantic salmon. One major difficulty in the correct assessment of plasma GH levels is related to the pulsatile nature of GH release in fish as in other higher animals (Le Bail et al., 1991; Boujard and Leatherland, 1992; Niu et al., 1993). The beneficial effects of GH administration on the improvement of seawater adaptation and smoltification of Atlantic salmon (Boeuf et al., 1990) have been demonstrated. But the absence of any spccific increase in plasma GH levels in response to dietary arginine levels in this study and the relatively low levels in seawater-adapted Atlantic salmon fed the experimental diets require confirmation through further specific studies to evaluate the effects of dietary arginine on overall somatotropic action.

\section{References}

Anderson, J.S., Lall, S.P., Anderson, D.M. and McNiven, M., 1993. Quantitative lysine requirement for Atlantic salmon (Salmo salar) fingerlings. Can. J. Fish. Aquat. Sci., 50: 316-322.

Association of Official Analytical Chemists. 1990. In: K. Helrich (Editor), Official Methods of Analysis. Association of Official Analytical Chemists, Arlington, VA, $1298 \mathrm{pp}$.

Björnsson B.T., Ogasawara, T., Hirano, T., Bolton, J.P. and Bern, H.A., 1988. Elevated growth hormone levels in stunted Atlantic salmon, Salmo salar. Aquaculture, 73: 275-281.

Björnsson B.T., Thorarensen, H., Hirano, T., Ogasawara, T. and Kristinnson, J.B., 1989. Photoperiod and temperature affect plasma growth hormone levels, growth, condition factor and hyperosmoregulatory ability of juvenile Atlantic salmon, Salmo salar. Aquaculture, 82: 77-91.

Bligh, E.G. and Dyer, W.J., 1959. A rapid method of total lipid extraction and purification. Can. J. Biochem. Physiol., 37: 911-917. 
Boeuf, G., Le Bail, P.Y. and Prunet, P., 1989. Growth hormone and thyroid hormones during Atlantic salmon, Salmo salar L., smolting, and after transfer to seawater. Aquaculture, 82: 257-268.

Boeuf, G., Prunet, P. and Le Bail, P.Y., 1990. Un traitement à l'hormone de croissance peut-il stimuler la smoltification du saumon atlantique? CR Acad. Sci., 310, Sér. III: 75-80.

Boujard, T. and Leatherland, J.F., 1992. Diet pattern of hepatosomatic index, liver glycogen and lipid content, plasma non-esterified fatty acids, glucose, $T_{3}, T_{4}$, growth hormone and cortisol concentrations in Oncorhynchus mykiss held in different photoperiod regimes and fed using demand feeders. Fish Physiol. Biochem., 10: 111-122.

Brookes, I.M., Owens, F.N. and Garrigus, U.S., 1972. Influence of amino acid level in the diet upon amino acid oxidation by the rat. J. Nutr., 102: 27-36.

Chiu, Y., Austic, R.E. and Rumsey, G.L., 1986. Urea cycle activity and arginine formation in rainbow trout (Salmo gairdneri). J. Nutr., 116: 1640-1650.

Chiu, Y., Austic, R.E. and Rumsey, G.L., 1988. Effect of feeding level and dietary electrolytes on the arginine requirement of rainbow trout (Salmo gairdneri). Aquaculture, 69: 79-91.

Cho, C.Y., Kaushik, S. and Woodward. B., 1992. Dietary arginine requirement of young rainbow trout (Oncorynchus mykiss). Comp. Biochem. Physiol., 102A: 211-216.

Cvancara, V.A., 1969. Studies on tissue arginase and ureogenesis in fresh water teleosts. Comp. Biochem. Physiol., 30: 489-496.

Fajans, S.S. and Floyd, J.C., 1972. Stimulation of islet cell secretion by nutrients and by the gastrointestinal hormones released during digestion. In: D.F. Steiner and N. Freinkel (Editors), Handbook of Physiology, Section 7, Endocrinology, Vol. 1, Williams and Wilkins, pp. 473-493.

Gehrke, C.W., Wall, L.L.S., Absheer, J.S., Kaiser, F.E. and Zumwalt, R.W., 1985. Sample preparation for chromatography of amino acids: acid hydrolysis of proteins. J. Assoc. Off. Anal. Chem., 68 (5) 811-821.

Huggins, A.K., Skutsch, G. and Baldwin, E., 1969. Ornithine urea cycle enzymes in teleost fish. Comp. Biochem. Physiol., 28: 587-602.

Kaushik, S.J., 1979. Application of a biochemical method for the estimation of amino acid needs of fish: quantitative argine requirements of rainbow trout in different salinities. In: K. Tiews and J.E. Halver (Editors), Proceedings, World Symposium on Finfish Nutrition and Fishfeed Technology, Hamburg, Vol. I, Heinemann Verlagsgesellschaft GmbH, Berlin, pp. 197-207.

Kaushik, S.J. and Fauconneau, B., 1984. Effects of lysine administration on plasma arginine and on some nitrogenous catabolites in rainbow trout. Comp. Biochem. Physiol. 79A(3): 459-462.

Kaushik, S.J., Fauconneau, B., Terrier, L. and Gras, J., 1988. Arginine requirement and status assessed by different biochemical indices in rainbow trout (Salmo gairdneri R.). Aquaculture, 70: 75-95.

Ketola, H.G., 1983. Requirement for dietary lysine and arginine by fry of rainbow trout. J. Anim. Sci., 56: 101-107.

Kim, K.I., Kayes, T.B. and Amundson, C.H., 1992. Requirement for lysine and arginine by rainbow trout (Oncorhynchus mykiss). Aquaculture, 106: 333-344.

Klein, R.G. and Halver, J.E., 1970. Nutrition of salmonid fishes: arginine and histidine requirements of chinook and coho salmon. J. Nutr., 100: 1105-1110.

Le Bail, P.Y., Sumpter, J.P., Carragher, J.F., Mourot, B., Niu, P.D. and Weil, C., 1991. Development and validation of a highly sensitive radioimmunoassay for chinook salmon (Oncorhynchus tshawytscha) growth hormone. Gen. Comp. Endocrinol., 83: 75-85.

Luquet, P. and Sabaut, J.J., 1974. Nutrition azotée et croissance chez la daurade et la truite. Acetes Coll., Coll. Aquacult., IFREMER, Brest, 1: 243-253.

National Research Council (1981). Nutrient Requirements of Coldwater Fishes. National Academy Press, Washington DC, 63 pp.

Niu, P.D., Perez-Sanchez, J. and LeBail, P.Y., 1993. Development of a protein binding assay for teleost insulin-like growth factor ( $\mathrm{GF}$ )-like: relationships between growth hormone (GH) and IGF-like in the blood of rainbow trout (Oncorhynchus mykiss). Fish Physiol. Biochem., 11:381391.

Nose, T., 1979. Summary report on the requirements of essential amino acids for carp. In: J.E. Halver 
and K. Tiews (Editors), Finfish Nutrition and Fishfeed Technology, Vol. I. Heenemann GmbH and Co., Berlin, pp. 145-156.

Ogino, C., 1980. Requirements of carp and rainbow trout for essential amino acids. Bull. Jpn. Soc. Sci. Fish., 46: 171-174.

Pickering, A.D., Pottinger, T.G., Sumpter, J.P., Carragher, J.F. and Le Bail, P.Y., 1991. Effects of acute and chronic stress on the levels of circulating growth hormone in the rainbow trout, Oncorhynchus mykiss. Gen. Comp. Endocrinol., 83: 86-93.

Plisetskaya, E.M., Leibush, B.N. and Bondareva, V.M., 1976. The secretion of insulin and its role in cyclostomes and fish. In: TaA.I. Grillo, L. Leisbon and A. Epple (Editors), The Evolution of Pancreatic Islets, Pergamon Press, Oxford, pp. 251-269.

Plisetskaya, E.M., Dickhoff, W.W., Paquette, T.L. and Gorbman, A., 1986. The assay of salmon insulin in homologous radioimmunoassay. Fish. Physiol. Biochem., 1: 37-43.

Plisetskaya, E.M., Buchelli-Narvaetz, L.I., Hardy, R.W. and Dickhoff, W.W., 1991. Effects of injected and dietary arginine on plasma insulin levels and growth of Pacific salmon and rainbow trout. Comp. Biochem. Physiol., 98A: 165-170.

Portugal, T.R. and Aksnes, A., 1983. Arginase activity in different fish species and tissues. Comp. Biochem. Physiol., 76B: 15-16.

Robbins, K.R., Norton, H.W. and Baker, D.H., 1979. Estimation of nutrient requirements from growth data. J. Nutr., 109:1710-1714.

Robinson, E.H., Wilson, R.P. and Poe, W.E., 1981. Arginine requirement and apparent absence of lysine-arginine antagonist in fingerling channel catfish. J. Nutr., 111: 46-52.

Santiago, C.B., 1985. Amino acid requirements of nile tilapia. Ph. D. thesis, Auburn University, Auburn, Alabama, USA. $126 \mathrm{p}$.

Santiago, C.B. and Lovell, T., 1988. Amino acid requirements for growth of nile tilapia. J. Nutr., 118 : $1540-1546$.

Steel, R.G.D. and Torrie, J.H., 1960. Principles and Procedures of Statistics. McGraw-Hill Book Company, Inc., New York, $481 \mathrm{pp}$.

Sundby, A., Eliassen, K.A., Blom, A.K. and Aasgaard, T., 1991. Plasma insulin, glucagon, glucagonlike peptide (GLP) and glucose levels in response to feeding, starvation and life long restricted feed ration in salmonids. Fish Physiol. Biochem., 9: 253-259.

Swanson, D.R., 1990. Somatomedin C and arginine: implicit connections between mutually isolated literatures. Persp. Biol. Med., 33: 157-186.

Visek, W.J., 1984. An update of concepts of essential amino acids. Annu. Rev. Nutr., 4: 137-155.

Visek, W.J., 1985. Arginine and disease states. J. Nutr., 115: 532-541.

Visek, W.J., 1986. Arginine needs, physiological state and usual diets: a reevaluation. J. Nutr., 116 : $36-46$.

Walton, M.J., Coloso, R.M., Cowey, C.B. and Adron, J.W., 1984. The effect of dietary tryptophan levels on growth and metabolism on rainbow trout (Salmo gairdneri). Br. J. Nutr., 51: 279-287.

Walton, M.J., Cowey, C.B, Coloso, R.M. and Adron, J.W., 1986. Dietary requirements of rainbow trout for tryptophan, lysine and arginine determined by growth and biochemical measurements. Fish Physiol. Biochem., 2: 161-169.

Wilson, R.P., 1989. Amino acids and proteins. In: J.E. Halver (Editor), Fish Nutrition, 2nd edn. Academic Press, Inc., New York, pp. 112-153.

Wilson, R.P. and Cowey, C.B., 1985. Amino acid composition of whole body tissue of rainbow trout and Atlantic salmon. Aquaculture, 48: 373-376.

Zeitoun, I.H., Ulirey, D.E., Magee, W.T., Gill, J.L. and Bergen, W.G., 1976. Quantifying nutrient requirements of fish. J. Fish. Res. Board Can., 33: 167-172. 